\title{
Risks in emerging markets: logistics services in the Mediterranean region
}

\author{
Amir Moslemi \\ Tradevarious Ltd., Helsinki, Finland \\ Olli-Pekka Hilmola \\ Kouvola Unit, Lappeenranta University of Technology, \\ Kouvola, Finland, and \\ Jyri Vilko \\ School of Business and Management, \\ Lappeenranta University of Technology, Lappeenranta, Finland
}

\begin{abstract}
Purpose - This study aims to explore and analyzes the risk factors in container shipping and logistics services using a dual perspective. The authors gather data not only from logistics service companies but also from their most important customers.

Design/methodology/approach - In this research, the authors used case study methodology (interviews and surveys) to examine risk factors that are related to one another within the interaction between logistics service companies and their customers in the emerging markets of the Mediterranean region (Turkey, Algeria, Tunisia and Libya).

Findings - The findings show the most important risk factors and compare them using a dual perspective. Customers identify additional risks and estimate their consequences as wider. Interestingly, oil price change plays a dual role because a price increase could be beneficial to the region; at the same time, however, the competitiveness of shipping would decrease. In both response groups, risk likelihood and risk consequence have a positive and statistically significant correlation.

Research limitations/implications - The findings of the study are limited to one shipping/logistics service company. On a global scale, the company is medium-sized; however, in terms of Northern Europe, it is an important player. Extending its service portfolio to the Mediterranean region is an important step.

Practical implications - In emerging markets, risks go hand in hand with profitability, and companies need to apply extensive risk analysis and mitigation strategies to survive.

Social implications - The southern Mediterranean region is showing some signs of economy recovery. Efficient, robust supply chains are in demand to support sustainable growth.

Originality/value - Using a case study approach in supply chain risk management in shipping is rather rare; this work is ground-breaking in that it uses dual perspective in the analysis.
\end{abstract}

Keywords Emerging markets, Risk analysis, Shipping, Containers

Risks in emerging markets

Paper type Case study

(C) Pacific Star Group Education Foundation 
MABR

1,3

\section{Introduction}

Emerging markets can be defined as countries that invest in increasing productive capacity. Leaders and governments in emerging markets want to create a better quality of life for their people. Thus, they industrialize rapidly and adopt a free market or mixed economy. Emerging markets are important for several reasons: first, they have a lower-than-average per capita income; second, they provide rapid growth; third, the capital markets are less mature; and finally, they provide higher-than-average return for investors (Amadeo, 2016). They drive growth in the global economy. The analysis of risks in these markets is important because, for instance, rapid social change in these areas could lead to high volatility. This study addresses a comprehensive picture of risk in container shipping operations in several emerging markets. Activity involves multiple entities, including shippers, forwarders, terminal operators and shipping companies. The complex operations within and between these entities and the long distance of physical process may give rise to various types of operational risks, which could negatively affect the performance of container shipping companies. This makes it important to analyze the extent to which each risk factor affects a logistics service company's performance and to identify the relative importance of these risk factors.

There are many kinds of risks in container shipping operations; however, this study focuses on the operational risks inherent in nearly every part of the supply chain and transportation activities related to containerized cargo. Here, the risk is simply defined and considered in terms of the probabilities of expected outcomes (Beaver, 1966)

Previous studies have provided valuable insight into the operational risks faced by container shipping industries in their operations (Ewert, 2008; Manuj and Mentzer, 2008a, 2008b; Drewry, 2009; Talley, 1996; Husdal and Brăthen, 2010; Notteboom, 2006; Tummala and Schoenherr, 2011; Chang et al., 2015). However, most of these studies have focused on one or more operational risk factors from a single point of view; no study has inclusively examined the possible operational risks faced from a dual perspective of both the logistics service provider and its customers. When considering the perspective of a logistics service regarding supply chain risk and the studies that have examined this perspective, it becomes obvious that previous literature has focused mainly on the supplier perspective, and the customer viewpoint is neglected in many respects. The importance of customer perspective in service risk management has been underlined by several authors (Vilko and Ritala, 2014; Niranjan and Weaver, 2011). However, research on the subject is still sparse, especially in the context of logistics. Indeed, engaging the customer perspective has become an increasing concern in logistics, as noted in the latest literature (Wagner and Sutter, 2012; Murfield and Esper, 2016). A study linking both the service provider and customer perspectives would be useful in helping logistics service providers and their customers to mitigate their operational risks. Obviously, investments and efforts should be made there, where risks are having higher significance.

In short, this study examines the key risk factors faced by the container shipping industry from the dual perspective of logistics service companies and their customers (located in Turkey, Algeria, Tunisia and Libya). The research will examine the risk factors that are related to the contribution of each of these two parties. The research represents a ground-breaking study in several ways. While some studies analyze risk in container shipping companies from the perspective of the company (Chang et al., 2015), there is no research that includes the customer perspective as well. Furthermore, Chang 
et al. (2015) have studied the risk factors faced by the container shipping companies in Taiwan; however, less distant (European) and different markets have not received any interest. Our material arises from the context of short-sea container shipping, which is increasingly significant because regional transport containers are used with ever more frequency for all sort of items, even raw materials such as coal (Yang et al., 2016).

With this in mind, our research investigates the risks of a container logistics service company (headquartered in Finland and active in 21 countries, including Turkey and North Africa) as a case study and its customers in the Mediterranean region. The study aimed at answering these questions:

$R Q 1$. What are the risk factors in container shipping operations from the perspectives of both the logistics service company and the customer?

$R Q 2$. What are the most important risk factors in the container shipping industry? How are they best controlled?

This manuscript is structured as follows: In Section 2 below, we shall review the theoretical background of the research area by examining previous research in the field. Section 3 describes the research methods that were used. The study comprised two phases: first, interviews were used to validate our questionnaire and themes; later, a survey was completed by both the logistics company and its most important customers in the region of concern. Section 4 presents empirical findings and analysis. Section 5 presents our conclusions, along with directions for possible future research.

\section{Theoretical background}

An increasing amount of risk in supply chains has been a trend in logistics for more than a decade (Minahan, 2005). Some studies have identified risk as the most important reason, why the desired performance is not achieved in the supply chain (Tummala and Schoenherr, 2011; Hendricks et al., 2009). The need for further study of risk is clear from the latest research, as well as the problems that companies face in coping with the uncertainties of the supply chain (Lam and Dai, 2015; Wiengarten et al., 2016).

By its nature, risk is a multidimensional construct. It has thus been defined in a multitude of ways (Zsidisin and Ritchie, 2008). For example, in finance literature, risk is considered in terms of the probabilities of expected outcomes (Beaver, 1966). The concept of risk has its historical roots in the first part of the twentieth century, in the Mediterranean region, where it was used to describe different things as "danger or hazard" (Giddens, 2002); this became the basis for insuring merchant ships. In the past, the concept of risk had different meanings in different languages and its etymology is not clear (Althaus, 2005). However, in contemporary language, as in most supply chain management literature, risk is defined as purely negative and seen as an event leading to undesired results or consequences (Harland et al., 2003; Manuj and Mentzer, 2008a, 2008b). The most commonly used quantitative definition of supply chain risk is based on the product of the probability of a risk event and the impact of that event (Mitchell, 1995). The risk formula is based on the assessor's subjective understanding of the event and can be considered a knowledge-based evaluation of it (Aven, 2012). Typically, risks are categorized according to their sources (Vilko, 2012). The selection and definition of the categories of risk (which can be weighted, compared and quantified) is arguably the most important step of the risk assessment process (Blackhurst et al., 2008). In general, the sources can be classified into two categories: endogenous and exogenous, depending 
MABR 1,3

on whether they are deriving from within or outside at the system - or in this case, the supply chain (Trkman and McCormack, 2009).

From the perspective of risk management, it is important to identify the most relevant risks according to their impact and frequency (Tang, 2006). First, operational risk events are those that occur regularly but are minor in terms of impact; therefore, their consequences to supply chain operations are not deemed serious. Second, disruptive risks are those described as low-probability, high-consequence events that may unexpectedly disrupt supply chain operations at any time.

The process of supply chain risk management consists of three main phases (Waters, 2007; Vilko, 2012). The first phase is risk identification, in which decision makers become aware of risk events. In the second phase, risk assessment, the relative importance of risk events is measured and analyzed. In the third phase, risk management action, proper responses to risk events are determined, carried out and monitored. Typically, the performance of supply chain risk management systems is highly dependent on the supply chain's holistic management (Sandhu and Helo, 2010). This highlights the importance of gaining a multi-perspective picture of supply chain risk and how the inter-organizational relationships in supply chains have become increasingly important (Soosay et al., 2008). Indeed, from the perspective of supply chain risk management, an organization's loss is incurred as a result of its vulnerability to a risk event (Wagner and Bode, 2006).

It is widely recognized in management research that the customer is the eventual party receiving the (value from) products and services (Vargo and Lusch, 2004; Grönroos and Ravald, 2011). One of the most important objectives of supply chain is therefore customer satisfaction (Kamalahmadi and Parast, 2016). While the importance of customer perspective has been emphasized in supply chain risk management, this sub-group of risk is addressed by few scholars in the literature (Murfield and Esper, 2016; Vilko and Ritala, 2014; Schröder, 2011). For risk management to function properly and holistically, the decision makers need to understand how risks are perceived by different actors in the supply chain. By studying a comprehensive, dual perspective of risk, this study addresses an important gap in the literature.

With regard to risk in container shipping, a number of studies are noteworthy. Drewry (2009) identified a list of business process and asset risks in container transport and logistics. These included documentation, booking and invoicing errors, errors in customs regulatory compliance and security compliance, strikes and transport congestion, theft and cargo loss or damage, piracy and terrorist attacks (Drewry, 2009).

The risk factors associated with information flow, which have been addressed in previous studies, may be grouped into three categories: information delay, information inaccuracy and information technology (IT) problems. Chang et al. (2015), Forrester (1961) and Lee et al. (1997) found that information asymmetry or lack of communication could lead to inaccurate or distorted information flow in a supply chain. Tummala and Schoenherr (2011) suggested that lack of necessary IT, or IT failure, ought to be considered an important risk element associated with information flow because they might disrupt the process of information transmission. Swabey (2009) stated that IT infrastructure breakdown is a risk factor. The service schedule's unreliability is also a risk factor in container shipping because it could lead to transportation delays and affect shipping companies' reputations (Notteboom 2006). 
Disruption risk is also considered to be a main factor in risk management. According to Tang (2006), disruption risk refers to major disruptions caused by natural and man-made disasters such as earthquakes, floods, hurricanes and terrorist attacks or economic crises such as currency fluctuations or employee strikes.

Based on a large-scale survey, Vernimmen et al. (2007) reported that over 40 per cent of the vessels deployed on worldwide liner services arrive one or more days behind schedule. They found several risk factors that might cause transportation delays, including bad weather at sea, congestion or labor strikes at the various ports of call and consequences of delays suffered at previous ports.

Tummala and Schoenherr (2011) stated that terrorism and war might also lead to disruption risk. This issue is currently more critical in the Middle East and Africa.

The inappropriate repositioning of empty containers can result in significant costs to shipping lines (Song and Dong, 2011); this, too, should be included as a risk in the container shipping industry.

Notteboom and Vernimmen (2009) used a cost model to simulate the impact of bunker cost changes on the operational costs of liner services. The results showed that a rise in oil prices might force shipping lines to reduce speed, which in turn would increase their operational costs and risks.

According to the abovementioned studies and other literature, a total of 38 risk factors were identified through literature review.

\section{Research methods}

\subsection{Risk identification}

Rao and Goldsby (2009) developed a comprehensive typology of supply chain risk management. They reviewed a wide range of literature to cover all the possible risk factors in the supply chain. The typology comprises five sources of risk in the supply chain, including environmental risk, industry risk, organizational risk, problem-specific risk and, finally, decision-maker risk. Our research used this typology to classify the risk factors.

For risk identification to be inclusive, the research first identified all the risk factors addressed in previous studies through an extensive literature review (e.g. used by Waters, 2007). Then, to determine whether the risks addressed in the broad range of literature could be applied to container shipping, the research used face-to-face interviews in a logistics service company. The interviews were conducted with six senior managers from different departments in two regions - the Mediterranean region and Finland. We were also interested in other risks that had not yet been addressed in literature.

With regard to the customer perspective, we conducted three additional interviews from three customers (different industries) in the Mediterranean region to determine which risk factors were identified (and probably add or modify existing ones). While most of the customers were large corporations, some could also be considered small companies - both in this survey and in the next. The companies dealt with food and agricultural products, as well as cosmetics and some chemical companies in the region.

In the following, we analyze separately and together this dual perspective of risk in logistics services. Analysis ends to correlation analysis and statistical significance testing of two perspective group answers within and between these two groups (concerning risk likelihood and risk consequence). 
MABR

1,3

\subsection{Risk measurement}

Generally, quantitative risk measurement uses two factors - risk likelihood and risk consequences (Mitchell, 1995; Waters, 2007; Cox, 2008; Beretta and Bozzolan, 2008). Risk likelihood is the probability that a risk caused by a risk source will occur, and risk consequence is the outcome or the potential outcome of a risk event. The risk scale is obtained by multiplying the risk likelihood with the relevant risk consequence (Cox, 2008; Tummala and Schoenherr, 2011).

To describe the likelihood and probability of the risks, we assigned values of 1,2, 3,4 and 5 to each risk to represent "rare", "unlikely", "possible", "likely" and "almost certain" (Yang, 2010). The level of risk consequence has been described in different ways. In this study, "insignificant", "minor", "moderate", "major" and "catastrophic", represented by the numbers 1-5, were used to describe the level of risk consequence (Chang et al., 2015). To identify and measure the level of likelihood and consequence of the risk factors, we conducted a survey, in the form of a questionnaire, using a five-point Likert scale in the four target countries of Turkey, Algeria, Tunisia and Libya. There were two types of questionnaire: one for logistics service companies and one for customer companies. In each country, the respondents were four senior managers and four employees from the logistics service company and eight representatives of the customer company.

\subsection{Risk analysis}

The study used the same method utilized by Chang et al. (2015) for risk analysis. They calculated a risk scale for each risk factor by multiplying likelihood and consequences. They then created a map to compare the relative importance of risk factors. In this method, characters are defined as follows:

- $N$ : the total number of respondents;

- $l_{r i}$ : the likelihood of risk factor $\mathrm{r}$ by the respondent, $i$; and

- $c_{r i}$ : the consequence of risk factor $r$ by the respondent, $i$.

Note that the risk scale is the product of the likelihood and the consequence of a risk factor. The method is to first obtain the risk scale for each respondent on each risk factor and then calculate the average of the scales across all respondents. Chang et al. (2015) referred to this method as average risk scale (ARS). The formula is as follows:

$$
A R S_{r}=\frac{1}{N} \sum_{i=1}^{N}\left(l_{r i} \times c_{r i}\right)
$$

\subsection{Data collection}

In summary, there were 39 risk factors identified through literature review and interviews. The factors were classified into five categories (environmental risk, industrial risk, organizational risk, problem-specific risk and decision-maker risk), according to the typology developed by Rao and Goldsby (2009). Tables I-V explain these risk factors in detail.

During the interviews, the interviewees confirmed almost all the risk factors identified in the literature review. The only risk factor, which was not confirmed as a risk was "Attack from pirates". All respondents agreed that it is not a risk in the 


\begin{tabular}{|c|c|c|c|}
\hline Code & Risk factors & Authors & \\
\hline Env_1 & Natural disasters and fire & $\begin{array}{l}\text { Miller (1991) and Chopra } \\
\text { and Sodhi (2004) }\end{array}$ & markets \\
\hline Env_2 & War, terrorism and political uncertainty & $\begin{array}{l}\text { Tang (2006) and Shubik } \\
\text { (1983) }\end{array}$ & \\
\hline Env_3 & $\begin{array}{l}\text { Processing documents detained by government } \\
\text { agencies (e.g. customs) }\end{array}$ & $\begin{array}{l}\text { Husdal and Bråthen (2010) } \\
\text { and Yang (2010) }\end{array}$ & 259 \\
\hline Env_4 & $\begin{array}{l}\text { Port congestion (unexpected waiting times before } \\
\text { berthing or before starting to load/discharge) }\end{array}$ & $\begin{array}{l}\text { Notteboom (2006); Drewry } \\
\text { (2009) and Tummala and } \\
\text { Schoenherr (2011) }\end{array}$ & \\
\hline Env_5 & Unstable weather & $\begin{array}{l}\text { Notteboom (2006) and } \\
\text { Husdal and Bråthen (2010) }\end{array}$ & \\
\hline Env_6 & Oil price rise & $\begin{array}{l}\text { Rao and Goldsby (2009) and } \\
\text { Notteboom and Vernimmen } \\
\text { (2009) and Husdal and } \\
\text { Bråthen (2010) }\end{array}$ & \\
\hline Env_7 & Cargo stolen from sealed containers & $\begin{array}{l}\text { Drewry (2009) and Husdal } \\
\text { and Bråthen (2010) }\end{array}$ & \\
\hline Removed & Attack by pirates & $\begin{array}{l}\text { Drewry (2009), Fu et al. } \\
\text { (2010) and Tummala and } \\
\text { Schoenherr (2011) }\end{array}$ & Table I. \\
\hline Env_8 & $\begin{array}{l}\text { Excessive handling because of border crossings or to } \\
\text { change in transportation modes }\end{array}$ & Chopra and Sodhi (2004) & $\begin{array}{r}\text { Environmental risk } \\
\text { factors (Env) }\end{array}$ \\
\hline Code & Risk factors & Authors & \\
\hline Ind_1 & Industrywide capacity utilization & $\begin{array}{l}\text { Miller (1991) and Chopra } \\
\text { and Sodhi (2004) }\end{array}$ & \\
\hline Ind_2 & Number of customers & Chopra and Sodhi (2004) & \\
\hline Ind_3 & Competitive uncertainty & Miller (1991) & \\
\hline Ind_4 & Product value & Chopra and Sodhi (2004) & Table II. \\
\hline Ind_5 & Supply and demand uncertainty & $\begin{array}{l}\text { Miller (1991) and Chopra } \\
\text { and Sodhi (2004) }\end{array}$ & $\begin{array}{r}\text { Industry risk factors } \\
\text { (Ind) }\end{array}$ \\
\hline
\end{tabular}

Mediterranean region; because it had not happened before, it was removed from questionnaire.

In addition to the previously identified risk factors, a number of additional factors were suggested. Pricing procedures and their associated risks were seen as a risk factor that could happen during the decision-making process. For instance, if the market is very competitive, companies sometimes need to decrease the regular prices to win the market or in some cases to survive. Another risk factor suggested by the interviewees was "Lack of innovation and innovative culture inside the organization". The idea of being innovative and having entrepreneurial intentions inside the organization has been widely discussed in innovation management literature. Gailly (2011) argues that the innovativeness of an organization can also 


\section{MABR}

1,3

\begin{tabular}{ll}
\hline Code & Risk factors \\
\hline Org_1 & $\begin{array}{l}\text { Labor productivity below expectations due to } \\
\text { unsafe work place, dispute, strikes, etc. }\end{array}$
\end{tabular}

\section{0}

Org_2

Use of different communication channels in the supply chain, consequently increasing the time of information transmission (e.g. telephone, e-mail, EDI)

Org_3 Lack of information security during the information flow

Org_4 Information asymmetry/incompleteness

Org_5 Lack of information standardization and compatibility

Org_6 IT infrastructure breakdown or crash

Org_7 Unsuitable human operation on IT infrastructure

Org_8 Unsuitable human operation on application software

Org_9 Supply chain partners not transmitting essential information on time

Org_10 Port/terminal productivity below expectations (loading/discharging)

Org_11 Inappropriate empty container transportation

Org_12 Lack of flexibility of fleet size and designed schedules

Org_13 Damage to containers or cargo due to terminal operators' improper loading/unloading operations

Org_14 Damage to ship or quay due to improper berth operations

Org_15 Change of currency exchange rate during payment process

Org_16 Payment delay from partners or shippers

Org_17 Suppliers or shippers' bankruptcy

Table III.

Organizational risk Org_18 factors (Org)
Financial strength and liquidity of logistics service company/customers
Authors

Notteboom (2006); Drewry

(2009), Husdal and Bråthen

(2010) and Tummala and

Schoenherr (2011) and Miller

(1991)

Metters (1997)

Sharma and Gupta (2002), Finch

(2004) and Qi and Zhang (2008)

Forrester (1961), Lee et al. (1997),

Angulo et al. (2004) and Husdal

and Bråthen (2010)

Tummala and Schoenherr (2011)

Qi and Zhang (2008), Swabey

(2009) and Tummala and

Schoenherr (2011) and Chopra

and Sodhi (2004)

Millman (2007)

Millman (2007)

Angulo et al. (2004) and Yang (2010)

Notteboom (2006) and Tummala and Schoenherr (2011)

Song et al. (2005) , Drewry (2006)

and (Song and Dong (2011)

Song et al. (2005); Qi and Song

(2012)

Husdal and Bråthen (2010)

Talley (1996) and Husdal and

Bråthen (2010)

Tummala and Schoenherr (2011)

Seyoum (2009)

Husdal and Bråthen (2010) and

Tummala and Schoenherr (2011)

Tummala and Schoenherr (2011)

be improved by raising its ability to identify and capture new opportunities, outside its current scope of activity. The additional risk factors suggested by the interviewees are Dec_5 and Dec_6. They are highlighted in italics in Table V. To facilitate the narrative, the study used short names to code the risk elements (sub-categories). 


\section{Risk analysis}

\subsection{Results of risk scaling}

The questionnaire was sent to a total of 64 respondents. The total number of replies from both perspectives was 31 , so the overall response rate was 48.43 per cent. This could be considered to be a good response rate. However, the number of answers is biased toward logistics service company, as only six valid responses were received from customers. The risk scales of the 39 risk factors calculated using the ARS function mentioned before. Table VI displays their mean values, standard deviations and the rankings (according to risk scale) among all risk factors.

In terms of the logistics service company perspective, the top three high-level risk factors are "Change of currency exchange rate during payment process" (Org_15: 8.92), "Number of customers" (Ind_2: 8.72) and "Product value" (Ind_4: 8.40). In addition, industry risk is the most significant one (the mean is 7.50) among the five categories of risks.

With regard to the customer company perspective, the top three risk factors are "Oil price rise" (Env_6: 10.33), "War, terrorism and political uncertainty" (Env_2: 10.00) and "Natural disasters and fire" (Env_1: 9.83). The most significant risk categories are problem-specific risks (the mean value is 7.75) and environmental risks (the mean value is 7.60). Remarkably, of all the risk factors, "Oil price rise" (Env_6) ranks first for the

\begin{tabular}{lllr}
\hline Code & Risk factors & Authors & \\
\hline Pro_1 & Outsourcing activities & Kotabe et al. (2008) & Table IV. \\
Pro_2 & Damage caused by transporting dangerous goods & Talley (1996) and Husdal & Problem-specific risk \\
& & and Brăthen (2010) & factors (Pro) \\
\hline
\end{tabular}

\begin{tabular}{lll}
\hline Code & Risk factors & Authors \\
\hline Dec_1 & $\begin{array}{l}\text { Dependency on a single source of supply, as well } \\
\text { as capacity and responsiveness of alternative } \\
\text { suppliers }\end{array}$ & Chopra and Sodhi (2004) \\
Dec_2 & $\begin{array}{l}\text { Business risk from shipping cycles, decisions } \\
\text { about buying, selling or chartering ships } \\
\text { The decision maker's detailed knowledge/skill/ } \\
\text { experience/biases of the overall risk framework } \\
\text { and issues involved therein }\end{array}$ & Stopford (1997) \\
Dec_3 & $\begin{array}{l}\text { Miss-investments or over-investments (if } \\
\text { investments completed in inadequately in wrong }\end{array}$ & Stopford (1997) \\
moment) & $\begin{array}{l}\text { Pricing procedures and the risks associated with } \\
\text { them }\end{array}$ & Outcome of interviews \\
Lack of innovation and innovative culture inside & Outcome of interviews \\
Dec_6 & the organization &
\end{tabular}

Note: Italic texts just indicate that these were the outcome of the interviews completed in case company

Table V. Decision-making risk factors (Dec) 
MABR

1,3

\begin{tabular}{|c|c|c|c|c|c|c|}
\hline \multirow[b]{2}{*}{ Risk factor } & \multicolumn{3}{|c|}{$\begin{array}{l}\text { Logistics service company } \\
\text { perspective }\end{array}$} & \multicolumn{3}{|c|}{$\begin{array}{l}\text { Customer company } \\
\text { perspective }\end{array}$} \\
\hline & Risk scale & $\mathrm{SD}$ & Rank & Risk scale & $\mathrm{SD}$ & Rank \\
\hline Env_1 & 5.44 & 5.15 & 22 & 9.83 & 8.06 & 3 \\
\hline Env_2 & 4.24 & 4.27 & 34 & 10.00 & 8.34 & 2 \\
\hline Env_3 & 6.00 & 4.89 & 15 & 5.50 & 3.99 & 36 \\
\hline Env_4 & 6.36 & 4.29 & 14 & 5.83 & 3.06 & 31 \\
\hline Env_5 & 5.40 & 4.03 & 24 & 6.50 & 4.14 & 26 \\
\hline Env_6 & 8.16 & 5.99 & 4 & 10.33 & 5.43 & 1 \\
\hline Env_7 & 4.08 & 3.49 & 36 & 6.50 & 3.51 & 26 \\
\hline Env_8 & 2.84 & 2.93 & 39 & 6.33 & 6.06 & 28 \\
\hline Mean of environmental risk factors & 5.31 & & & 7.60 & & \\
\hline Ind_1 & 5.96 & 4.25 & 16 & 5.50 & 3.99 & 36 \\
\hline Ind_2 & 8.72 & 5.87 & 2 & 7.50 & 3.21 & 13 \\
\hline Ind_3 & 7.72 & 5.79 & 6 & 7.50 & 4.93 & 13 \\
\hline Ind_4 & 8.40 & 6.17 & 3 & 6.67 & 5.82 & 24 \\
\hline Ind_5 & 6.72 & 3.92 & 9 & 6.83 & 5.64 & 19 \\
\hline Mean of industry risk factors & 7.50 & & & 6.80 & & \\
\hline Org_1 & 5.88 & 5.89 & 17 & 7.33 & 5.43 & 16 \\
\hline Org_2 & 4.68 & 3.92 & 31 & 7.33 & 5.09 & 16 \\
\hline Org_3 & 4.72 & 3.72 & 29 & 5.17 & 6.15 & 39 \\
\hline Org_4 & 6.52 & 5.10 & 12 & 5.67 & 6.06 & 33 \\
\hline Org_5 & 5.28 & 4.60 & 25 & 6.83 & 5.74 & 19 \\
\hline Org_6 & 6.48 & 5.43 & 13 & 8.33 & 9.03 & 10 \\
\hline Org_7 & 5.68 & 6.09 & 19 & 6.83 & 9.43 & 19 \\
\hline Org_8 & 4.72 & 5.32 & 29 & 8.17 & 9.00 & 11 \\
\hline Org_9 & 5.76 & 5.32 & 18 & 5.67 & 5.85 & 33 \\
\hline Org_10 & 5.68 & 2.91 & 19 & 8.17 & 9.52 & 11 \\
\hline Org_11 & 4.52 & 4.17 & 32 & 6.00 & 6.13 & 29 \\
\hline Org_12 & 4.96 & 5.15 & 26 & 5.67 & 6.06 & 33 \\
\hline Org_13 & 7.20 & 4.51 & 7 & 9.17 & 9.68 & 7 \\
\hline Org_14 & 3.92 & 3.37 & 38 & 7.50 & 9.12 & 13 \\
\hline Org_15 & 8.92 & 7.40 & 1 & 9.50 & 8.85 & 5 \\
\hline Org_16 & 7.84 & 6.08 & 5 & 9.50 & 8.85 & 5 \\
\hline Org_17 & 4.48 & 4.22 & 33 & 9.67 & 8.07 & 4 \\
\hline Org_18 & 6.60 & 5.62 & 10 & 9.17 & 6.11 & 7 \\
\hline Mean of organizational risk factors & 5.76 & & & 7.54 & & \\
\hline Pro_1 & 4.76 & 3.92 & 28 & 6.67 & 3.67 & 24 \\
\hline Pro_2 & 4.16 & 2.77 & 35 & 8.83 & 6.74 & 9 \\
\hline Mean of problem-specific risk factors & 4.46 & & & 7.75 & & \\
\hline Dec_1 & 4.80 & 4.28 & 27 & 7.00 & 9.32 & 18 \\
\hline Dec_2 & 6.84 & 5.53 & 8 & 5.83 & 3.31 & 31 \\
\hline Dec_3 & 4.04 & 3.43 & 37 & 6.83 & 4.67 & 19 \\
\hline Dec_4 & 6.56 & 5.71 & 11 & 6.83 & 3.49 & 19 \\
\hline Dec_5 & 5.44 & 4.35 & 22 & 6.00 & 4.65 & 29 \\
\hline Dec_6 & 5.56 & 4.52 & 21 & 5.33 & 4.08 & 38 \\
\hline Mean of decision-making risk factors & 5.54 & & & 6.30 & & \\
\hline Total average & 5.79 & & & 7.28 & & \\
\hline Total number of respondents & & & 31 & & & \\
\hline
\end{tabular}

Table VI.

Risk scale of all risk factors

\section{2}


customer company perspective and fourth for the logistics service company perspective. This suggests that this factor is the most serious one in container shipping operations.

\subsection{Results of risk mapping}

Risk mapping is a common method for analyzing the relative importance of different risk factors (Waters, 2007). In a risk map, the horizontal axis represents the risk likelihood, and the vertical axis represents the risk consequence. Each risk factor can be plotted on the risk map. Our study used the average likelihood and average consequence to derive a specific risk factor's likelihood and consequence over all respondents. Based on the risk scales, the map was divided into four regions: low-risk (corresponding to risk scale $<3)$, moderate-risk $(3<$ risk scale $<6)$, high-risk $(6<$ risk scale $<9)$ and extreme-risk $(9<$ risk scale).

As shown in the risk map for logistics service companies (Figure 1), the majority of the risk factors (27 out of 39) fall within the moderate-risk region. One risk factor falls within the low-risk region, "Excessive handling due to border crossings or to change in transportation modes" (Env_8). There are no risk factors in the extreme-risk region. A total of ten risk factors fall within the high-risk region, including Org_6, Dec_2, Ind_5, Ind_3, Ind_4, Ind_2, Org_15,Env_6, Org_16 and Org_13. Most of these factors belong to the categories of industry risk and organizational risk; this supports the finding that, with regard to logistics service company risks, industry risk is more significant than the other four categories because of its higher mean value on the risk scale. The total number of responses for the logistics service company perspective was 25.

In the risk map for customer companies (Figure 2), two risk factors, Env_6 and Org_17, are located in the extreme-risk region. There are 17 risk factors in the high-risk region, including Org_5, Env_7, Org_6, Org_1, Pro_1, Pro_2, Org_13, Ind_2, Org_16, Org_2, Org_8, Dec_4, Org_18, Env_1, Env_2, Org_15 and Ind_3. There are 20 risk factors in the moderate-risk region, but 6 of them (Org_14, Ind_4, Org_10, Dec_3, Ind_5 and Env_5) are close to the high-risk region. Of the 17 risk factors in the high-risk region, 9 are organizational risks. This suggests that, in container shipping operations, organizational risks have the most serious impact for the customer companies. The total number of responses for customer company perspective was six.

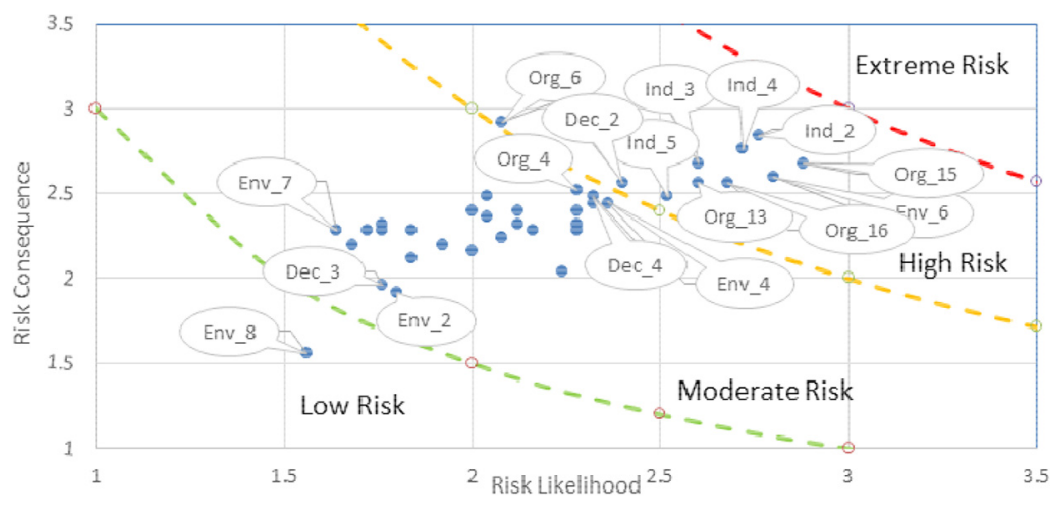

Note: $n=25$

Figure 1.

Risk map for logistics service companies across all respondents 
MABR

1,3

\section{4}

Figure 2.

Risk map for customer companies across all respondents

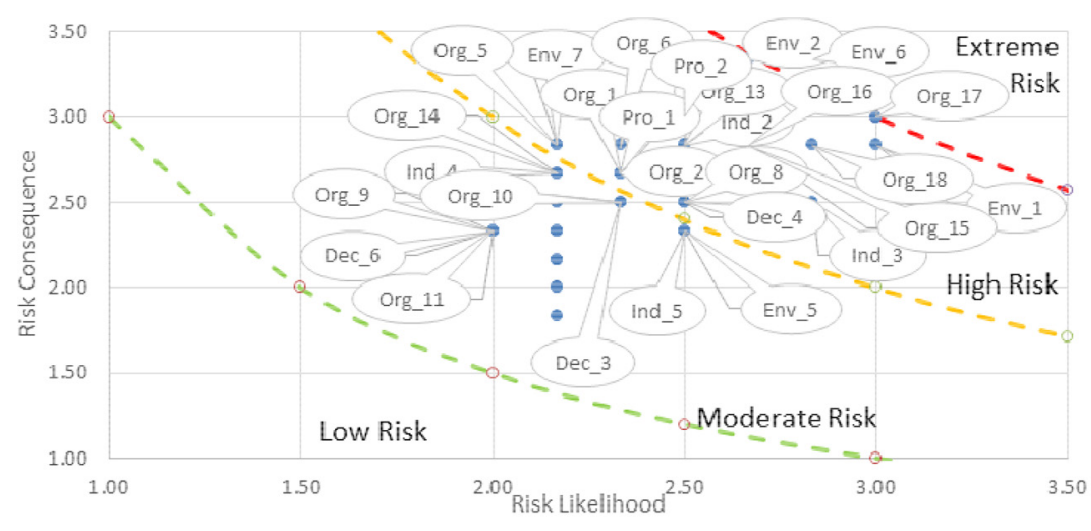

Note: $n=6$

Another important approach to interpreting the results is to find the common key risk factors between the supply chain partners (that is, the logistics service company and its customers). For this purpose, we identified seven high-risk factors the logistics service company and the customer companies have in common. These are Env_6, Ind_2, Ind_3, Org_6, Org_13, Org_15 and Org_16. These common risk factors were ranked using the ARS for both perspectives. The number one priority for both is "Oil price rise". The second priority is "Change of currency exchange rate during payment process", and the third one is "Payment delay from partners or shippers". It is worth mentioning that all seven factors are considered to be important issues for both sides.

\subsection{Correlation analysis}

To discover the exact correlation and the relative strength between the two variables of risk likelihood and risk consequence from a dual perspective, our research addressed these causalities using correlation analysis (Table VII). In this analysis, two groups of data sets were used: average risk likelihood and average risk consequence for two groups of respondents. According to analysis, the correlation of the logistics service company and the customer company responses regarding risk likelihood and risk consequence is strongly positive within these organizations; this relationship is highly significant in statistical terms (it is also in overall responses, these two groups together, having the same high statistical significance, not shown in Table VII). On the other hand, the correlation between the logistics service company and the customer company risk likelihood is again positive but not significant in statistical terms (6.1 vs 5 per cent). This emphasizes the previous findings and reveals that customers merely had a broader perspective on potential risks.

Other possible causalities do not exist. It is interesting to note that the understanding of risk consequence between customers and logistics service companies is having a very low reading. Therefore, these two groups understand the consequences in different ways, again illustrating that customers are more critical regarding risks as compared to logistics service companies. 


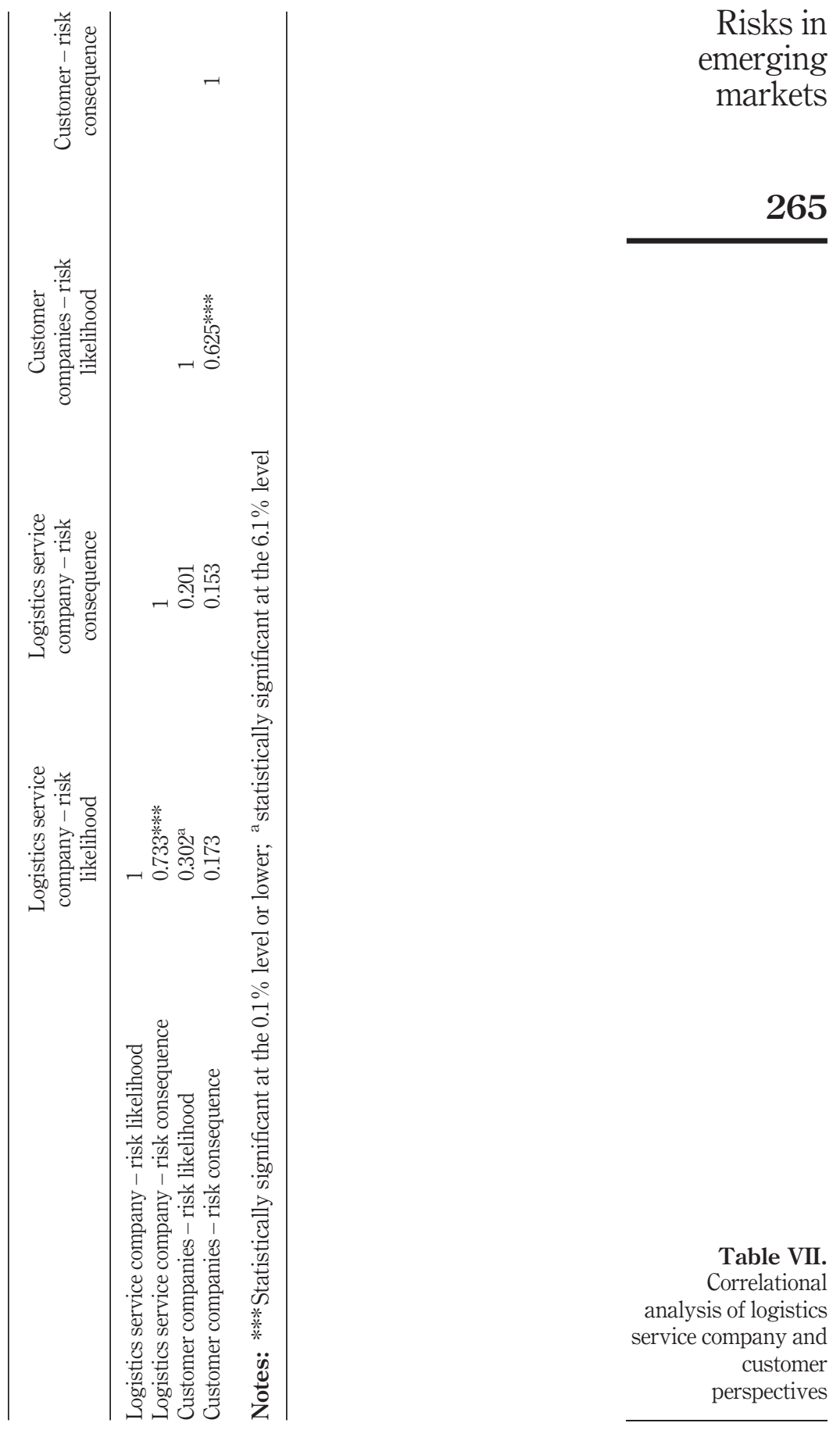


MABR

1,3

\section{Concluding discussion}

Our research used empirical data to analyze the risks faced by container shipping operations from a dual perspective. The purpose was to provide a comprehensive view of the risks in the container shipping industry. By averaging all risk factors in terms of their impact on logistics service companies and customer companies, the result (as shown in Table VI) reveals that customer companies are the most affected (the total average is 7.28), which means that they are more concerned about the risks existing in this business. This is an important finding, which logistics service companies should consider thoroughly (to not only improve the robustness of operations and mitigate risks but also illustrate that they do care about customer interface).

In this respect, it is worth mentioning several highlights. One is that the industry risk for logistics service companies and the problem-specific risk and environmental risk for the customer companies are the most important risk categories. If available resources are limited, it is recommended that manager give priority to these categories in designing risk control policies. The other highlight is that, of the 39 risk factors, Env_6, or "oil price rise", is the most serious factor with the highest risk scale. This emphasizes the importance of energy resources in every business, especially in transportation and logistics. The issue of increasing or decreasing oil prices has two clear implications in the Mediterranean region, especially for countries dependent on oil exports. First, if the price of oil decreases, shipping companies benefit from the lower costs for vessels; however, lower prices could have a significant negative effect on the economy and buying power of countries such as Algeria and Libya, where the economy is based on oil production. Clearly, the best strategy for managing this issue is the continuous monitoring of global market fluctuations. However, because forecasting market fluctuations is a difficult, sometimes impossible task, the companies could focus on decreasing the severity of the consequences of these issues. Companies can partner with third-party market analysis companies to develop strategies for coping with market fluctuations and control the financial loss from such changes. Another possible strategy is inventory holding or traditional hedging. The companies can buy and reserve oil, while the price is not stable, to reduce the financial damage incurred during that period of time. Furthermore, the risk factor of "Change of currency exchange rate during payment process" (Org_15) ranks first for the logistics service company perspective and fifth for the customer company perspective. This suggests that this factor is also one of the most serious risk factors in container shipping operations.

With regard to the previous findings from correlation analysis and the common risk management approach, the difference between the logistics service company and the customer's opinion is clear. According to the risk mapping results, most of the high-risk factors have been identified by the customers. This emphasizes the difference and shows that customers see risks everywhere. Customers identify numerous risks and think that their consequences are more severe.

\subsection{Scientific implications}

The findings of this study add to the scientific discussion of holistic supply chain risk management in two important ways. First, the study illustrates the importance of understanding the customer viewpoint in terms of risk and how a dual-perspective risk management process can help to gather further information on risk factors and their relative importance. The current scholarly discussion on supply chain risk management 
has clear gaps in terms of customer perspective risk management (Murfield and Esper, 2016). Second, this study illustrates the importance of the customers' viewpoint in the specific context of container transport. The current scholarly discussion addressing the customer perspective in supply chains has primarily been more general (e.g. customer value creation; see Vilko and Ritala, 2015; Kallionpää et al., 2014). As container logistics is the backbone of global trade, we argue that in order to manage supply chain risk in a sustainable way, the risks from the customer perspective must be taken into account. This issue is highlighted in the context of the logistics service supply chain, where customer demands and risks are increasing (Tummala and Schoenherr, 2011; Wiengarten et al., 2016), and thus the operations are more vulnerable to disturbances.

\subsection{Managerial implications}

This research provides useful insight for container shipping company managers and supply chain companies and can assist them in better understanding the risks in their operations and in differentiating their efforts on mitigating risks. The research recommends that managers in both types of companies collaborate to continually monitor and control the common risk factors. In this respect, participation in regular meetings with customers and, more importantly, a system of continual risk management analysis could be the best solutions to tackle this issue. These practices will help the managers on both sides to improve the decision-making process and increase the companies' agility and robustness to better cope with the risks.

Some risks are more important than others and could cause unwanted chains of events. These risks should be identified and controlled through a chain effective analysis to ensure that every aspect of these risks has been clarified and controlled. This could be discussed in future research.

It is also worth mentioning that the characteristics of risk in the Mediterranean region are slightly different from those of other regions. This difference stems from the different business culture and people's point of view. In this region, business owners have a different sensitivity to risk compared to their North or West European counterparts. For instance, in many western countries, the risk of "Using different communication channels in the supply chain and consequently increasing the time of information transmission" may be evaluated as a high-scale risk because time is a main factor in transportation services. However, as the results of this study showed, the abovementioned risk is evaluated in the Mediterranean region as a low-scale risk factor and held very little importance for those respondents.

\subsection{Limitations of the study}

There are three main limitations to this research. First, there are language differences. Although the majority of respondents to both the interviews and the questionnaires were able to understand and speak English, it must be remembered that the research was carried out in four non-English speaking countries (Turkey, Algeria, Tunisia and Libya). This could result in misunderstanding as to the nature of the risk factors and even to the project of risk management as a whole. The second limitation is geographical location. As explained above, the research aimed to analyze the risk factors in four Mediterranean countries. It may be difficult to generalize the results to other regions, such as Europe, because the business cultures are totally different. Finally, the number of respondents for the questionnaires and also the case company can be an issue. As 
MABR

1,3

explained before, the total number of respondents was 64, of which, 32 worked for the shipping company, and 32 worked for the customer companies. The total response rate was 48.43 per cent, which is usually considered as a good rate. However, the research was focused on a single case company in this industry, which is a weak point of the research. While there may be some similarities among shipping companies, generalization of this research to other shipping or supply chain companies is not recommended.

\subsection{Suggestions for future research}

Future research may focus on evaluating the relative performance of appropriate risk mitigation strategies in managing container shipping operations through the implementation of empirical practices in various regions. In addition, the development of a risk management tool that continually monitors the key risks could be another direction for further research.

\section{References}

Althaus, C.E. (2005), "A disciplinary perspective on the epistemological status of risk", Risk Analysis, Vol. 25 No. 3, pp. 567-588.

Amadeo, P. (2016), "What are emerging markets? Five defining characteristics and list", available at: www.thebalance.com/what-are-emerging-markets-3305927 (accessed 16 September 2016).

Angulo, A., Nachtmann, H. and Waller, M.A. (2004), "Supply chain information sharing in a vendor managed inventory partnership”, Journal of Business Logistics, Vol. 25 No. 1, pp. 101-120.

Aven, T. (2012), “The risk concept - historical and recent development trends", Reliability Engineering \& System Safety, Vol. 99, pp. 33-44.

Beaver, W. (1966), "Financial ratios as predictors failure", Journal of Accounting Research, Vol. 4 No. 3, pp. 71-111.

Beretta, S. and Bozzolan, S. (2008), "Quality versus quantity: the case of forward-looking disclosure”, Journal of Accounting, Auditing and Finance, Vol. 23 No. 3, pp. 333-376.

Blackhurst, V.J., Scheibe, P.K. and Johnson, J.D. (2008), "Supplier risk assessment and monitoring for the automotive industry", International Journal of Physical Distribution \& Logistics Management, Vol. 38 No. 2, pp. 143-165.

Chang, C.H., Jingjing, X. and Dong-Ping, S. (2015), "Risk analysis for container shipping: from a logistics perspective", Int. Journal of Logistics Management, Vol. 26 No. 1, pp. 147-171.

Chopra, S. and Sodhi, M. (2004), "Managing risk to avoid supply chain breakdown", MIT-Sloan Management Review, Vol. 46 No. 1, pp. 53-61.

Cox, L.A. (2008), “What's wrong with risk matrices?”, Risk Analysis, Vol. 28 No. 2, pp. 497-512.

Drewry (2006), Annual Container Market Review \& Forecast 2006/2007, Drewry Shipping Consultants, London.

Drewry (2009), Risk Management in International Transport and Logistics, Drewry Shipping Consultants, London.

Ewert, K. (2008), "Risk management”, Handbook of Container Shipping Management, Vol. 2 No. 33, pp. 71-85. 
Finch, P. (2004), "Supply chain risk management”, Supply Chain Management: An International Journal, Vol. 9 No. 2, pp. 183-196.

Forrester, J.W. (1961), Industrial Dynamics, MIT Press, Boston, MA.

Fu, X., Ng, A.K. and Lau, Y.Y. (2010), "The impacts of maritime piracy on global economic development: the case of Somalia", Maritime policy and management, Vol. 37 No. 7, pp. 677-697.

Gailly, B. (2011), Developing Innovative Organizations: A Roadmap to Boost Your Innovation Potential, Palgrave MacMillan, London.

Giddens, A. (2002), Runaway World: How Globalisation is Reshaping our Lives, Profile, London.

Grönroos, C. and Ravald, A. (2011), "Service as business logic: implications for value creation and marketing”, Journal of Service Management, Vol. 22 No. 1, pp. 5-22.

Harland, C., Brenchley, R. and Walker, H. (2003), "Risk in supply networks”, Journal in Purchasing and Supply Management, Vol. 9 No. 2, pp. 51-62.

Hendricks, K., Singhal, V. and Zhang, R. (2009), "The effect of operational slack diversification, and vertical relatedness on the stock market reaction to supply chain disruptions", Journal of operations management, Vol. 27 No. 3, pp. 233-246.

Husdal, J. and Bråthen, S. (2010), "Bad locations, bad logistics? How Norwegian freight carriers handle transportation disruptions", The World Conference for Transportation Research, Lisbon, July 2010.

Kallionpää, E., Rantala, J., Vilko, J. and Hemilä, J. (2014), "Identifying customer value in supply chains - the process of analysis", presented to The 19th International Symposium on Logistics, Ho Chi Minh City, Vietnam.

Kamalahmadi, M. and Parast, M.M. (2016), "A review of the literature on the principles of enterprise and supply chain resilience: major findings and directions for future research", International Journal of Production Economics, Vol. 171 No. 1, pp. 116-133.

Kotabe, M., Riege, A., Griffiths, K., Noble, G., Ang, S.H., Pecotich, A. and Helsen, K. (2008), International Marketing, Second Asia-Pacific Edition, Wiley, Brisbane.

Lam, J.S.L. and Dai, J. (2015), "Developing supply chain security design of logistics service providers: an analytical network process-quality function deployment approach", International Journal of Physical Distribution \& Logistics Management, Vol. 45 No. 7, pp. 674-690.

Lee, H.L., Padmanabhan, V. and Whang, S. (1997), "Information distortion in a supply chain: the bullwhip effect”, Management Science, Vol. 43 No. 4, pp. 546-558.

Manuj, I. and Mentzer, J.T. (2008a), "Global supply chain risk management strategies", International Journal of Physical Distribution and Logistics Management, Vol. 38 No. 3, pp. 192-223.

Manuj, I. and Mentzer, J.T. (2008b), "Global supply chain risk management”, Journal of business logistics, Vol. 29 No. 1, pp. 133-155.

Metters, R. (1997), "Quantifying the bullwhip effect in supply chain”, Journal of Operations Management, Vol. 15 No. 2, pp. 89-100.

Miller, K. (1991), "A framework for integrated risk management in international business", Journal of International Business Studies, Vol. 23 No. 2, pp. 311-331.

Millman, R. (2007), "Human error biggest threat to computer security", available at: www.itpro. co.uk/115920/human-error-biggest-threat-to-computer-security (23 August 2015). 
MABR

1,3

Minahan, T. (2005), The Supply Risk Benchmark Report, Aberdeen Group, Boston, MA.

Mitchell, V.W. (1995), “Organizational risk perception and reduction: a literature review”, British Journal of Management, Vol. 6 No. 2, pp. 115-133.

Murfield, M.L.U. and Esper, T.L. (2016), "Supplier adaptation: a qualitative investigation of customer and supplier perspectives", Industrial Marketing Management, available at: http://dx.doi.org/10.1016/j.indmarman.2016.02.004

Niranjan, T.T. and Weaver, M. (2011), "A unifying view of goods and services supply chain management”, The Service Industries Journal, Vol. 31 No. 14, pp. 2391-2410.

Notteboom, T.E. (2006), "The time factor in liner shipping services", Maritime Economics and Logistics, Vol. 8 No. 1, pp. 19-39.

Notteboom, T.E. and Vernimmen, B. (2009), "The effect of high fuel costs on liner service configuration in container shipping", Journal of Transport Geography, Vol. 17 No. 5, pp. 325-337.

Qi, X.T. and Song, D.P. (2012), "Minimizing fuel emissions by optimizing vessel schedules in liner shipping with uncertain port times", Transportation Research Part E, Vol. 48 No. 4, pp. 863-880.

Qi, Y. and Zhang, Q. (2008), "Research on information sharing risk in supply chain management", Proceedings of the International Conference on Wireless Communications, Networking and Mobile Computing, Dalian, pp. 1-6.

Rao, S. and Goldsby, T.J. (2009), "Supply chain risks: a review and typology”, International Journal of Logistics Management, Vol. 20 No. 1, pp. 97-123.

Ritchie, B. and Marshall, D. (1993), Business Risk Management, Chapman \& Hall, London.

Sandhu, M. and Helo, P. (2010), "Supply process development with an inter-organisational and intra-organisational perspective", International Journal of Logistics Systems and Management, Vol. 6 No. 2, pp. 235-248.

Schröder, R.W. (2011), "Aggregation of supply chain risks taking the end customer's perspective”, Social Science Research Network, Social Science Research Network (SSRN), Rochester, NY.

Seyoum, B. (2009), Export-Import Theory, Practices, and Procedures, Routledge, Oxon.

Sharma, S. and Gupta, J.N. (2002), "Securing information infrastructure from information warfare”, Logistics Information Management, Vol. 15 No. 5, pp. 414-422.

Shubik, M. (1983), "Political risk: analysis, process, and purpose”, Managing International Risk, Cambridge University Press, New York, NY.

Song, D.P. and Dong, J.X. (2011), "Flow balancing-based empty container repositioning in typical shipping service routes”, Maritime Economics and Logistics, Vol. 13 No. 1, pp. 61-77.

Song, D.P., Zhang, J., Carter, J., Field, T., Marshall, J., Polak, J. and Woods, J. (2005), “On cost-efficiency of the global container shipping network", Maritime Policy and Management, Vol. 32 No. 1, pp. 15-30.

Soosay, C., Hyland, P. and Ferrer, M. (2008), "Supply chain collaboration: capabilities for continuous learning”, Supply Chain Management: An International Journal, Vol. 13 No. 2, pp. 160-169.

Stopford, M. (1997), Maritime Economics, 2nd ed, Routledge, London.

Swabey, P. (2009), "European firms at risk of technological breakdown”, 10 December 2009, available at: www.information-age.com/it-management/skills-training-and-leadership/110 1952/european-firms-at-risk-of-technological-breakdown (accessed 26 August 2015). 
Talley, W.K. (1996), "Determinants of cargo damage risk and severity: the case of containership accidents", Logistics and Transportation Review, Vol. 32 No. 4, pp. 377-388.

Tang, C.S. (2006), "Perspectives in supply chain risk management", International Journal of Production Economics, Vol. 103 No. 2, pp. 451-488.

Trkman, P. and McCormack, K. (2009), "Supply chain risk in turbulent environments: a conceptual model for managing supply chain network risk", International Journal of Production Economics, Vol. 119 No. 2, pp. 247-258.

Tummala, R. and Schoenherr, T. (2011), “Assessing and managing risks using the supply chain risk management process (SCRMP)”, Supply Chain Management: An International Journal, Vol. 16 No. 6, pp. 474-483.

Vargo, S.L. and Lusch, R.F. (2004), "Evolving to a new dominant logic for marketing", Journal of Marketing, Vol. 68 No. 1, pp. 1-17.

Vernimmen, B., Dullaert, W. and Engelen, S. (2007), "Schedule unreliability in liner shipping: origins and consequences for the hinterland supply chain", Maritime Economics and Logistics, Vol. 9 No. 3, pp. 193-213.

Vilko, J. (2012), “Approaches to supply chain risk management: identification, analysis and control", $\mathrm{PhD}$ thesis, Acta Universitalis Lappeenrantaenis, Lappeenranta.

Vilko, J. and Ritala, P. (2014), "Service supply chain risk management", International Journal of Operations and Supply Chain Management, Vol. 7 No. 3, pp. 114-120.

Vilko, J. and Ritala, P. (2015), “Assessing service supply chain vulnerability from customer value perspective - multi-industry insights", presented to the 29th Annual Australian and New Zealand Academy of Management (ANZAM) Conference, Queenstown.

Wagner, S. and Bode, C. (2006), "An empirical investigation into supply chain vulnerability", Journal of Purchasing and Supply Management, Vol. 12 No. 6, pp. 301-312.

Wagner, S.M. and Sutter, R. (2012), "A qualitative investigation of innovation between third-party logistics providers and customers", International Journal of Production Economics, Vol. 140 No. 2, pp. 944-958.

Waters, C.D. (2007), Supply Chain Risk Management - Vulnerability and Resilience in Logistics, Biddles, King's Lynn, Norfolk, VA.

Wiengarten, F., Humphreys, P., Gimenez, C. and McIvor, R. (2016), "Risk, risk management practices, and the success of supply chain integration", International Journal of Production Economics, Vol. 171 No. 3, pp. 361-370.

Yang, D., Weng, J. and Hu, J. (2016), "Coal containerization - will it be an alternative mode of transport between north and south China in the future?", Maritime Business Review, Vol. 1 No. 1, pp. 76-87.

Yang, Y.C. (2010), "Impact of the container security initiative on Taiwan's shipping industry", Maritime Policy and Management, Vol. 37 No. 7, pp. 699-722.

Zsidisin, G.A. and Ritchie, B. (2008), Supply Chain Risk: A Handbook of Assessment, Management, and Performance, Springer Publishers, New York, NY.

\section{Further reading}

Wharton, F. (1992), "Risk management: basic concepts and general principles", in Ansell, J. and Wharton, F. (Eds), Risk: Analysis, Assessment and Management, John Wiley and Sons, Chichester, pp. 1-14. 
MABR 1,3

\begin{abstract}
About the authors
Amir Moslemi (MSc Tech) has graduated both from Iran and Finland. He has also studied in Belgium (Université catholique de Louvain) and worked in Germany (BASF SE, Ludwigshafen). Specialized in entrepreneurship, innovation management and risk management, he is able to capture the new opportunities in potential emerging markets. His latest project was done for an international shipping company on two locations in Baltic and Mediterranean Seas.

Olli-Pekka Hilmola is working as a Professor in Lappeenranta University of Technology (LUT) in research unit located in the city of Kouvola, Finland. He is affiliated with numerous internatioal journals through editorial boards, including Expert Systems with Applications, Industrial Management and Data Systems, as well as Decision Support Systems. He holds more than 150 journal publications and has been involved in numerous international research projects from logistics. Olli-Pekka Hilmola is the corresponding author and can be contacted at: olli-pekka.hilmola@lut.fi

Jyri Vilko (DSc Economics and Business Administration, MSc Tech) is a Post-Doctoral Researcher in the School of Business and Management at Lappeenranta University of Technology, Finland. His recent research interests are in the areas of supply chain risk management, inter-firm relations, service supply chains and value creation. He also holds a position of Adjunct Professor in Thammasat Business School, Thailand. He has published on these topics in high-quality academic journals such as International Journal of Production Economics, International Journal of Logistics Management and International Journal of Shipping and Transport Logistics. He has been involved in business practice with regard to these topics through his research and in speaker and advisory roles.
\end{abstract}

For instructions on how to order reprints of this article, please visit our website: www.emeraldgrouppublishing.com/licensing/reprints.htm Or contact us for further details: permissions@emeraldinsight.com 